\title{
SPACE MAPPING OF HIP AND WRISTS MOTIONS FOR DIFFERENT TRANSFER DISTANCES IN MANUAL MATERIAL HANDLING TASK
}

\author{
RAdin ZAID RADIN UMAR ${ }^{1,2^{*}}$, FATIN AYUNi MOHD AZLI LEE ${ }^{1}$, MUHAMMAD \\ NAQIUDDIN KHAFIZ ${ }^{1}$, NADIAH AHMAD ${ }^{1,2}$, NAZREEN ABDULLASIM ${ }^{3}$ \\ ${ }^{1}$ Fakulti Kejuruteraan Pembuatan, \\ ${ }^{2}$ Center of Smart System and Innovative Design, \\ ${ }^{3}$ Fakulti Teknologi Maklumat dan Komunikasi, \\ Universiti Teknikal Malaysia Melaka, Malaysia \\ *Corresponding author: radinzaid@utem.edu.my
}

(Received: $16^{\text {th }}$ July 2019; Accepted: $9^{\text {th }}$ March 2020; Published on-line: $4^{\text {th }}$ July 2020)

\begin{abstract}
Manual material transfer tasks are common in occupational settings. Repetitive lifting tasks usually involve twisting and bending which are associated with occupational lower back injuries. One of the approaches to reduce bending and twisting is to separate the distance between lifting origin and destination, which will encourage lifters to step and turn entire bodies. However, adding lifting distances is likely to affect space usages and requirements. A study was conducted to investigate how the transfer distances influence space usage during the lifting task. Raw data of hip and hand wrists motion of 26 male subjects during transfer in 4 different distances were captured using $\mathrm{X}$-Sens motion capture system. MVN Studio software was used to process and extract positional data. Tabulated space mapping revealed limited hip movement and semicircular shaped hand motions for short transfer distances. The pattern changes into a more stretched-curve shape as the distance increases. Overall, it was observed that shorter transfer distance caused participants to adopt more twisting and less bending postures, while further transfer distances resulted in more bending and less twisting. This study may provide industrial practitioners with information to design a space requirement for manual material transfer tasks.
\end{abstract}

ABSTRAK: Kerja-kerja pemindahan barang secara manual adalah biasa dalam persekitaran kerja. Kerja-kerja mengangkat barang yang kebiasaannya melibatkan badan membengkok dan berpusing boleh menyebabkan kecederaan tulang belakang. Salah satu cara bagi mengurangkan risiko ini adalah dengan memisahkan jarak antara tempat asal dan tempat tuju pemindahan barang. Pemindah barang digalakkan untuk melangkah dan memusingkan seluruh badan. Namun, cara ini menyebabkan penggunaan ruang yang banyak. Satu kajian telah dijalankan bagi mengkaji bagaimana jarak pemindahan barang mempengaruhi penggunaan ruang ketika kerja-kerja pemindahan. Data asal pergerakan pinggul dan pergelangan tangan daripada 26 subjek lelaki ketika pemindahan barang pada 4 jarak berbeza diperolehi menggunakan sistem rakaman gerakan X-Sens. Perisian MVN Studio digunakan bagi memproses dan mengekstrak data ini. Ruang pemetaan berjadual mendedahkan pergerakan pinggul yang terhad dan pergerakan tangan berbentuk separa bulat pada jarak pemindahan terdekat. Corak ini berubah kepada bentuk lengkung memanjang apabila jarak bertambah. Keseluruhannya, jarak pindahan yang kurang menyebabkan para peserta lebih terdedah kepada postur memusingkan badan berbanding membengkok, sementara jarak yang jauh menyebabkan peserta lebih membengkok berbanding memusingkan badan. Kajian ini memberikan maklumat untuk 
penggiat industri mereka cipta keperluan ruang bagi kerja-kerja pemindahan barang secara manual.

KEYWORDS: space mapping; ergonomics; manual material handling; transfer distance

\section{INTRODUCTION}

Application of ergonomic principles has shown good results in increasing productivity and decreasing health issues [1]. Ergonomics consideration in early stage s of workplace design has been shown to yield better outcomes compared to considerations at later design stages. Front end ergonomics involves looking into interfaces between workers and workplace elements such as workstation, task, and work environment. One of the components of front-end ergonomics is the evaluation of work layout, which specifically looks into space requirements.

Manual material handling $(\mathrm{MMH})$ activities are one of the most common tasks in workplaces. High frequency and long duration of exposure to $\mathrm{MMH}$, especially in the industry that still relies on manual labour, can directly impact the workers as they are more likely to be exposed to ergonomic risk factors related to MMH activities [2]. Multiple studies have discussed potential methods to minimize ergonomic risk factors due to $\mathrm{MMH}$ such as training [3], assisting devices [4], and workplace layout design [5,6]. However, there have been publications suggesting limited effectiveness of training for preventing lower back pain $[7,8]$. Assisting devices may also minimize ergonomic related risks, however high tech devices may come at a cost, and there might be resistance to adopt them due to unfamiliarity and slowing down the processes [9].

Workplace layout and space play a direct role in influencing workers' movements and postures. Poor layout and limited space may contribute to poor work postures for the workers [10]. Lavender and Johnson [6] argued that consideration of good workplace layout allows some degree of control on asymmetric lifting behaviour. In an other study, Mehta et. al. [5] outlined that separating the origin of the lift station and the destination at a certain distance may nurture workers to step and turn their whole body which may help reduce bending and twisting during the manual handling activity. It was suggested that distancing the location between lifts can limit the twisting of body. In an experimental study conducted in the United States of America, Lavender \& Johnson [6] revealed that lateral bending and twisting of the spine were minimized when a separation distance of 1 meter was created between the lift's origin and the destination. Poor work postures in combinations of repetitive and long exposure durations can increase risks of ergo no mics issues like sprain, strain, and work-related musculoskeletal disorders [11,12]. Therefore, a good design that focuses on optimizing interaction between workplace setup and workers can contribute to increased efficiency and productivity in a workplace [13].

In workstation design options to control ergonomic risk factors, existing ergo no mics guidelines have been primarily focused on space clearances. There have also been generic guidelines on manual material handling activities $[14,15]$ than can be referred prior to the design process. However, there has not been much information that specifically focuses on space requirement for manual material handling tasks. The objective of this study is to capture and map the hip and wrist motions during the manual material handling task. Specifically, box transfer processes of different transfer distances and their effect on the space requirement during the handling task have been selected as the focus of study. It is envisioned that space mapping of motions during manual material handling tasks can provide engineers and designers with space requirement information during the front-end 
manual material handling workstation design process. Thus, a deeper study focusing on interaction of workers and their space requirement may provide insights that can be utilized in the front-end design of workplaces.

\section{METHODOLOGY}

\subsection{Overview}

A randomized repeated design of experiment was conducted to map the space requirement behaviours of different transfer distances during manual handling activities. Space mapping data was collected through the use of 3D body motion capture system Xsens (Xsens Technologies, Netherlands). The system consisted of accelerometers that captured acceleration data at a sampling frequency of 30 data per second. The raw acceleration data were then converted into velocity data, and then positional data through a series of customized programming algorithms developed using Processing software.

\subsection{Subject Participants}

26 healthy male participants, age ranging from 23-24 years old (Mean $=23.88$, $\mathrm{SD}=0.35$ ) were recruited in this study. The subjects were screened to ensure that they were free of any history of musculoskeletal disorders or prior injuries that could affect the way they performed the tasks of interest. Other exclusion criteria include any injury within the past 12 months that caused them to restrict any work or non-work activity, and ex istence of current pain or other musculoskeletal symptoms.

\subsection{Data Collection}

Each subject signed consent forms and filled demographic data before wearing the Xsens sensor-integrated suit. The subject was then asked to transfer boxes of fixed weight $(10.9 \mathrm{~kg})$ between two stations, the heights of which were set so that the beginning and ending heights were at the 5 th percentile of Malaysian population elbow height $(0.913 \mathrm{~m})$ [16]. Lifting load and height were controlled to minimize their effect on experimental outcomes. Each subject was briefed on the simulated task, before being asked to practice transferring the boxes. After the practice session, subject was asked to continuously transfer 4 boxes in 4 different transfer distances of $0.50 \mathrm{~m}, 0.75 \mathrm{~m}, 1.00 \mathrm{~m}$, and $1.25 \mathrm{~m}$, as shown in Fig. 1. No specific instructions were given with regards to transfer te chniques. Figure 2 shows an example of one subject performing the box transfer task.
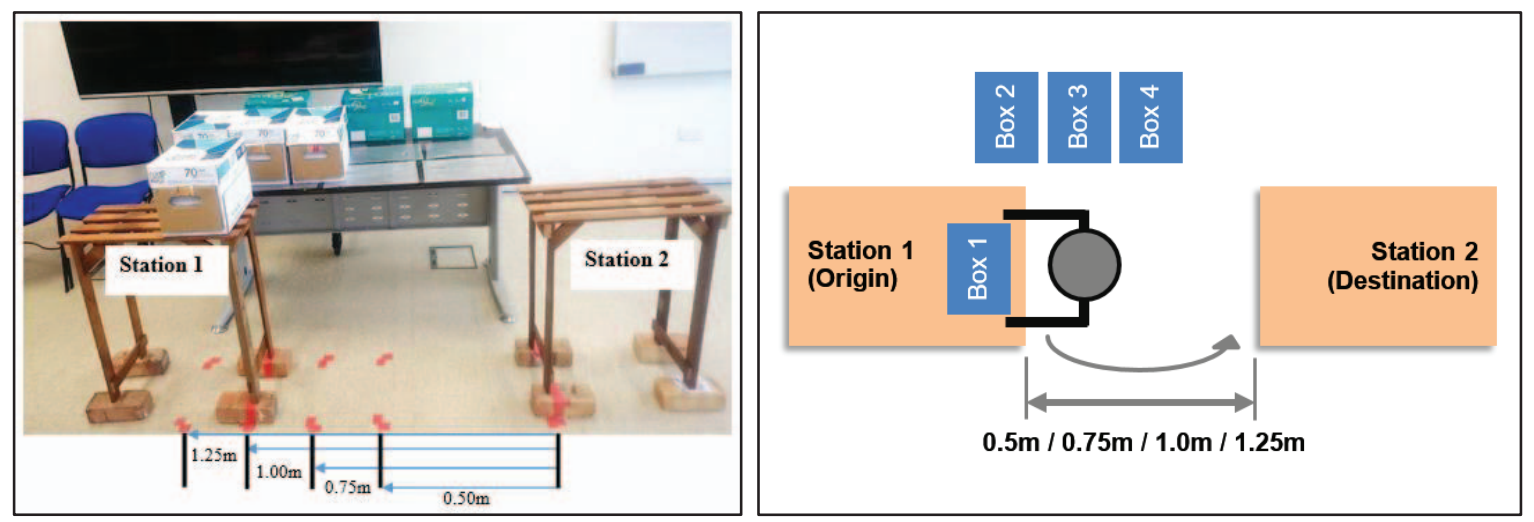

Fig. 1: Workstation setup (left), top view of experimental setup (right). 

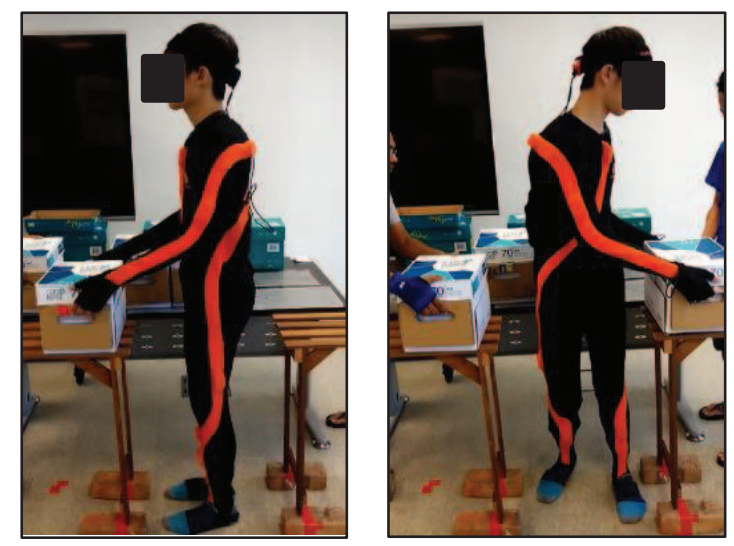

Fig. 2: Subject wearing motion capture system performing the box transfer task at $0.5 \mathrm{~m}$ distance set up.

\subsection{Data Processing and Analysis}

\subsubsection{Image Analysis}

Raw data from the Xsens motion capture system were extracted and visualized in MVN Studio software (Xsens Technologies, Netherlands). The 3D simulation was run for each subject to observe obvious trends and patterns on postural behaviours. Screen captures were taken at the 4 th cycle at both origin and destination of lifting for the purpose of image analysis. The observation of 4 th cycle data is to represent work postures during continuous transfer, as well as to allow subjects to be more at ease as task familiarization started to take place.

\subsubsection{Space Mapping Analysis}

Positional data of the hip and right and left wrists were obtained for each subject. These positional data, in $\mathrm{X}$ and $\mathrm{Y}$ planes were extracted using Cinema 4D software (MAXON Computer GmbH, Germany) that were then tabulated and mapped using Microsoft Excel.

The tabulation allows an overview of the motions from the top view. Each data was colour-coded to differentiate between the body parts (hip, right wrist, and left wrist), and between transfer distances $(0.5 \mathrm{~m}, 0.75 \mathrm{~m}, 1.0 \mathrm{~m}$, and $1.25 \mathrm{~m})$.

\subsubsection{Analysis on Width Requirements}

The maximum width distance requirements of each cycle from all transfer distances, across all subjects, were captured through identification of furthest positional data in an excel file. Descriptive statistics were used to analyse the differences in width requirements and consequently, in the area used by each subject. Repeated ANOVA measures were conducted using a JASP statistics package (Wagenmakers, Amsterdam) to see if there were significant differences on width requirements between different transfer distances. Mauchly's test was used for sphericity assumption. A post hoc comparison test was performed using Bonferroni correction to analyse the pairwise comparisons of experimental conditions. 


\section{RESULTS}

\subsection{Image Analysis}

Qualitative analysis was conducted through observation of images captured using MVN Studio software. It was conducted to identify the relation between bending and twisting postures with transfer distance from different subjects. Figure 3 and 4 show the bending postures whereas Fig. 5 and Fig. 6 show twisting postures of one of the subjects. Both were captured during the box lifting and placing at four different distances. For the twisting posture, the images were captured from the top view. It can be seen that the small transfer distance caused the subject to adopt more twisting but less bending posture. The observation was opposite for greater transfer distances.

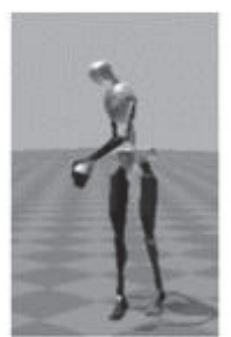

(a)

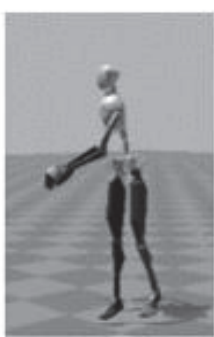

(b)

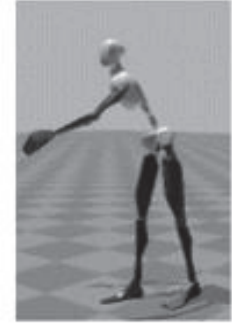

(c)

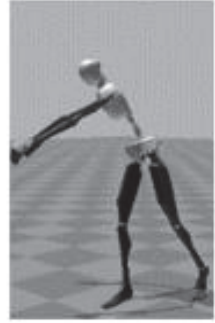

(d)

Fig. 3: Forward bending of a subject during the start of box lifting (origin) at four different transfer distances: (a) $0.50 \mathrm{~m}$, (b) $0.75 \mathrm{~m}$, (c) $1.00 \mathrm{~m}$, and (d) $1.25 \mathrm{~m}$.

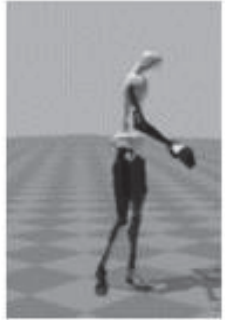

(a)

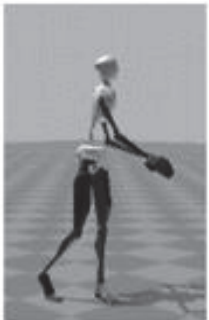

(b)

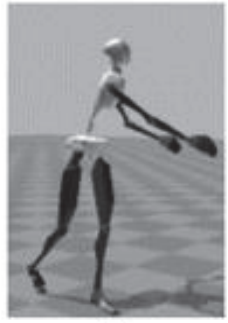

(c)

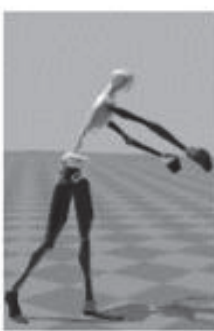

(d)

Fig. 4: Forward bending of a subject during the start of box placement (destination) at four different transfer distances: (a) $0.50 \mathrm{~m}$, (b) $0.75 \mathrm{~m}$, (c) $1.00 \mathrm{~m}$, and (d) $1.25 \mathrm{~m}$.

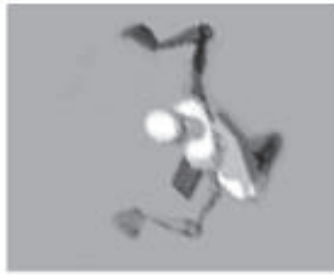

(a)

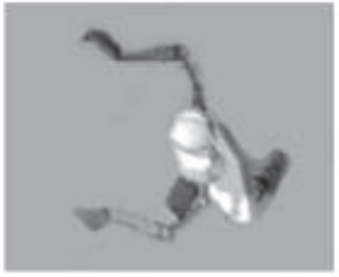

(b)

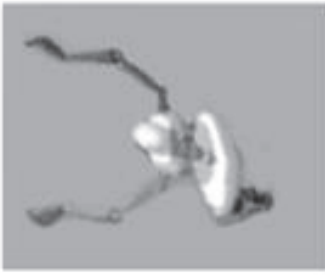

(c)

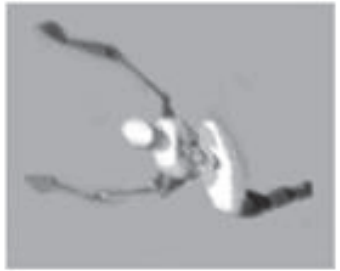

(d)

Fig. 5: Lower back twisting of a subject during the start of box lifting (origin) at four different transfer distances: (a) $0.50 \mathrm{~m}$, (b) $0.75 \mathrm{~m}$, (c) $1.00 \mathrm{~m}$, and (d) $1.25 \mathrm{~m}$. 


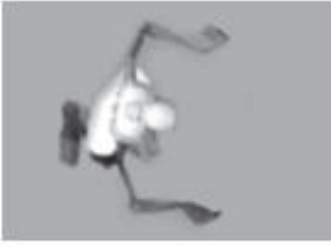

(a)

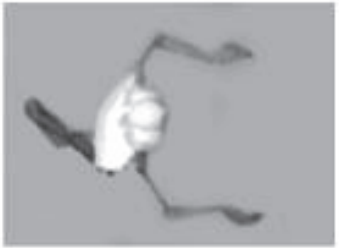

(b)

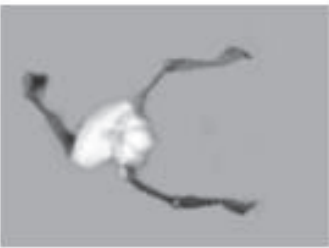

(c)

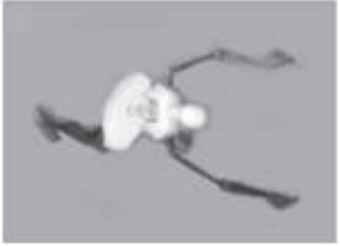

(d)

Fig. 6: Lower back twisting of a subject during the start of box placement (destination) at four different transfer distances: (a) $0.50 \mathrm{~m}$, (b) $0.75 \mathrm{~m}$, (c) $1.00 \mathrm{~m}$, and (d) $1.25 \mathrm{~m}$.

\subsection{Space Mapping Analysis}

In order to see the patterns of hip and wrist motions, graphs were plotted based on the maximum and minimum points of the hip and wrists for all subjects. Figure 7 shows the graphs of space mapping data for one subject at different transfer distances while Fig. 8 shows the graphs of space mapping of hip and wrists positional data for all subjects during the material handling activity. The starting point of each subject is facing the positive $\mathrm{x}$ axis from the origin.

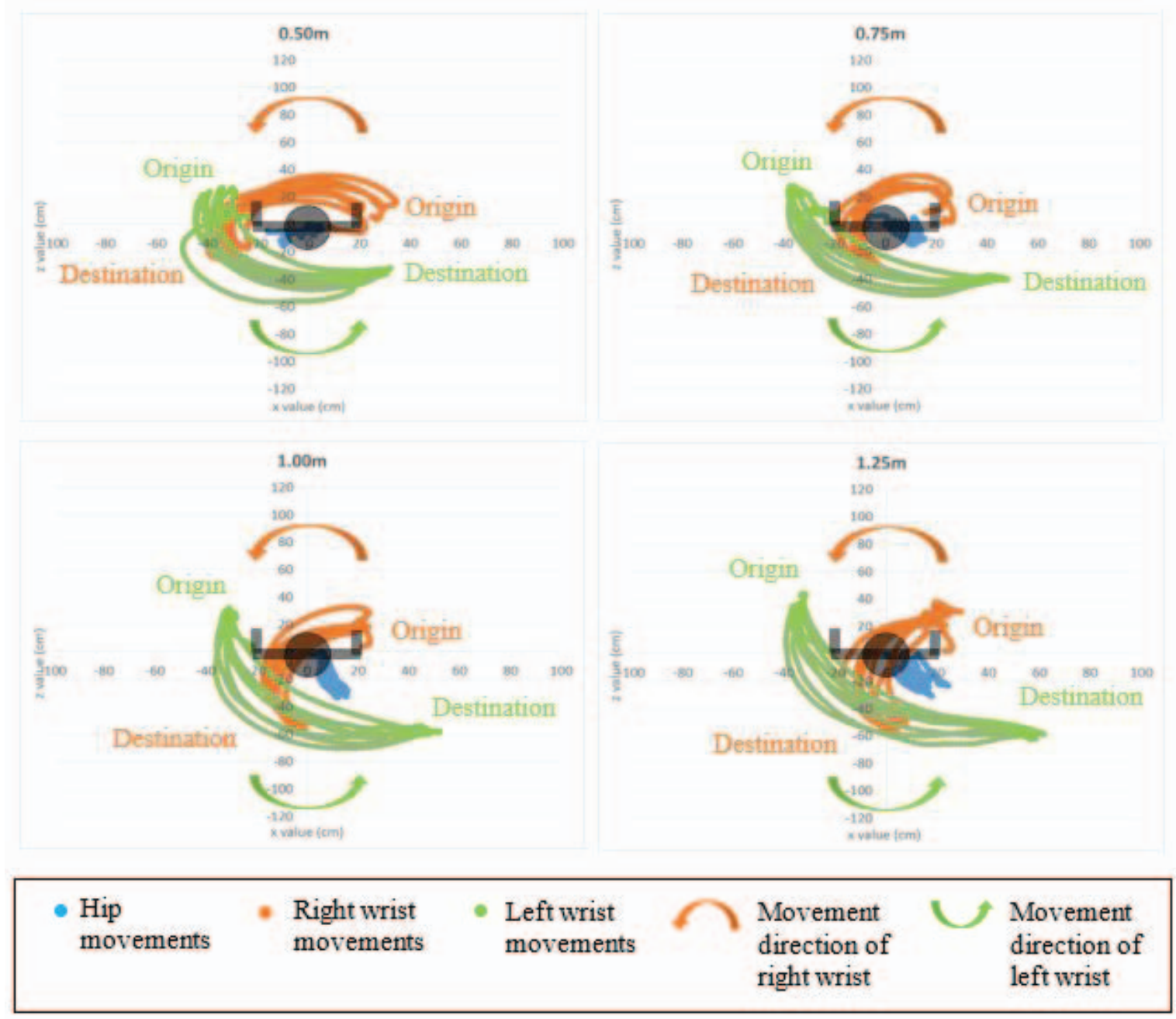

Fig. 7: Space mapping of wrists and hip motion of manual transfer for Subject 23 at $0.50 \mathrm{~m}, 0.75 \mathrm{~m}, 1.00 \mathrm{~m}$, and $1.25 \mathrm{~m}$ transfer distances. 
It can be seen from the space mapping analysis that more space was utilized during the transfer as the transfer distances increased. The hip movements in $0.5 \mathrm{~m}$ transfer distance were seen to be localized in the same area, between $20 \mathrm{~cm}$ in both $\mathrm{x}$ and $\mathrm{y}$ ax is. As the transfer distance increased, the hip movements were seen to be distributed over larger areas. At $1.25 \mathrm{~m}$ transfer distance, the hip movements were shown to be the largest compared to other distances, as shown in Fig. 8. A similar trend was observed with both right and left wrist movements. The space mapping data shows that movements of hip, right wrist, and left wrist occupied larger areas as the transfer distances increased from 0.5 $\mathrm{m}$ to $1.25 \mathrm{~m}$. In addition to the larger occupied area, it can also be seen that different transfer distances affected the movement direction and shape. As transfer distance increased, the hip tended to move further in the y axis direction. In terms of wrists, the movements expended from a semi-circular shape into stretched-out semi-circular shape.

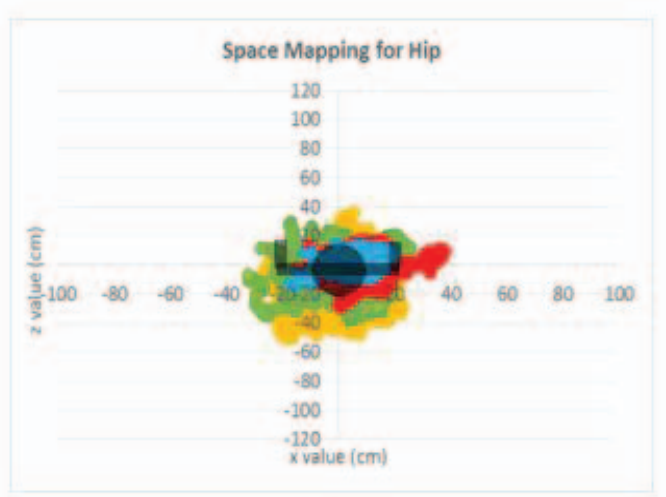

(a)

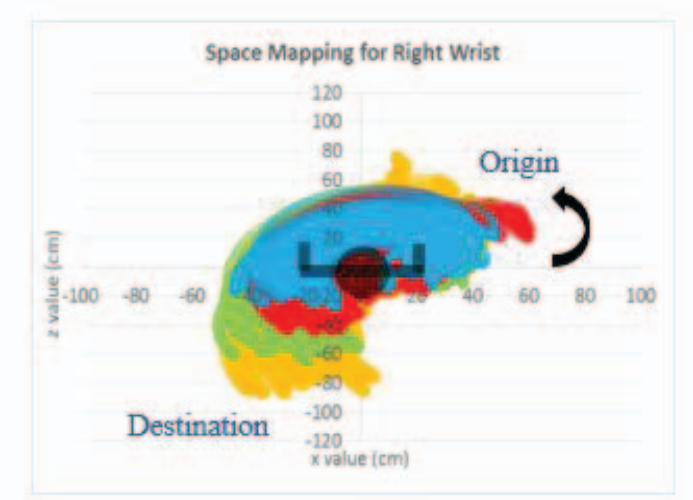

(b)

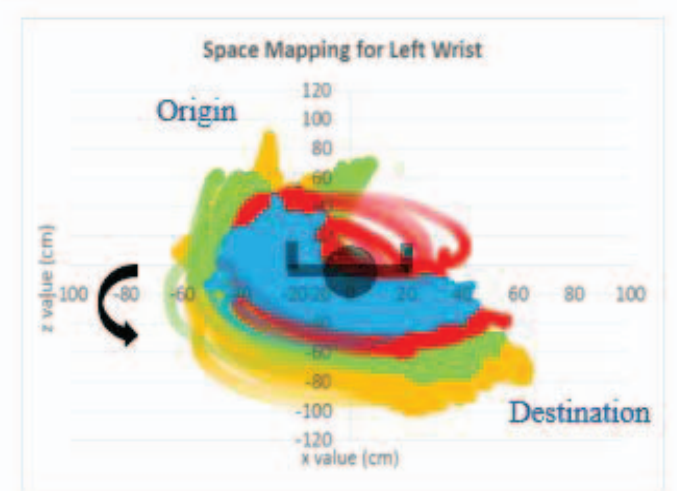

(c)

\begin{tabular}{|c|c|c|c|c|}
\hline $\begin{array}{l}\text { Movements } \\
\text { at transfer } \\
\text { distance } \\
0.50 \mathrm{~m}\end{array}$ & $\begin{array}{l}\text { Movements } \\
\text { at transfer } \\
\text { distance } \\
0.75 \mathrm{~m}\end{array}$ & $\begin{array}{l}\text { Movements } \\
\text { at transfer } \\
\text { distance } \\
1.00 \mathrm{~m}\end{array}$ & $\begin{array}{l}\text { Movements } \\
\text { at transfer } \\
\text { distance } \\
1.25 \mathrm{~m}\end{array}$ & $\begin{array}{l}\text { Movements } \\
\text { direction }\end{array}$ \\
\hline
\end{tabular}

Fig. 8: Mapping of (a) hip, (b) right wrist, and (c) left wrist movements for all 26 subjects at $0.50 \mathrm{~m}, 0.75 \mathrm{~m}, 1.00 \mathrm{~m}$, and $1.25 \mathrm{~m}$ transfer distances.

\subsection{Analysis on Width Requirements}

The positional data involved to map the top view of hip and wrist motions were $\mathrm{x}$ and $z$ points. The maximum value, average, and standard deviation of width at each transfer distance from all subjects were calculated and tabulated in Table 1. The values showed 
increase in space width from the shortest $(0.50 \mathrm{~m})$ to greatest $(1.25 \mathrm{~m})$ tran sfer distance. Figure 9 shows the graph of width average for subject 23 .

Mauchly's test showed good sphericity assumption $(p=0.129)$, which indic ated that the variances of the differences were equal. Repeated ANOVA measures showed that there was a significant effect of transfer distances $(p<0.001)$ on width require ments. The post hoc Bonferroni test to analyse the pairwise comparisons between the transfer distances showed significant differences between $0.5 \mathrm{~m}$ vs $1.25 \mathrm{~m}$, and $0.75 \mathrm{~m}$ v s $1.25 \mathrm{~m}$ at alpha $=0.05$. The width requirements for transfer distances between $0.5 \mathrm{~m}$ vs $0.75 \mathrm{~m}$, $0.50 \mathrm{~m}$ vs $1.0 \mathrm{~m}$, and $1.0 \mathrm{~m}$ vs $1.25 \mathrm{~m}$ were not statistically significant, as shown in Table 2 . It should be noted that the $0.75 \mathrm{~m}$ vs $1.0 \mathrm{~m}$ transfer distance showed marginal significance $(p=0.055)$.

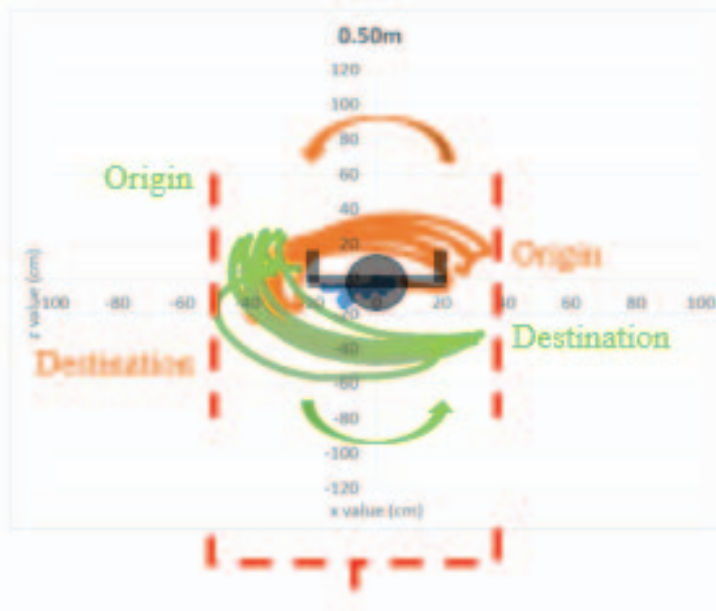

Width requirements

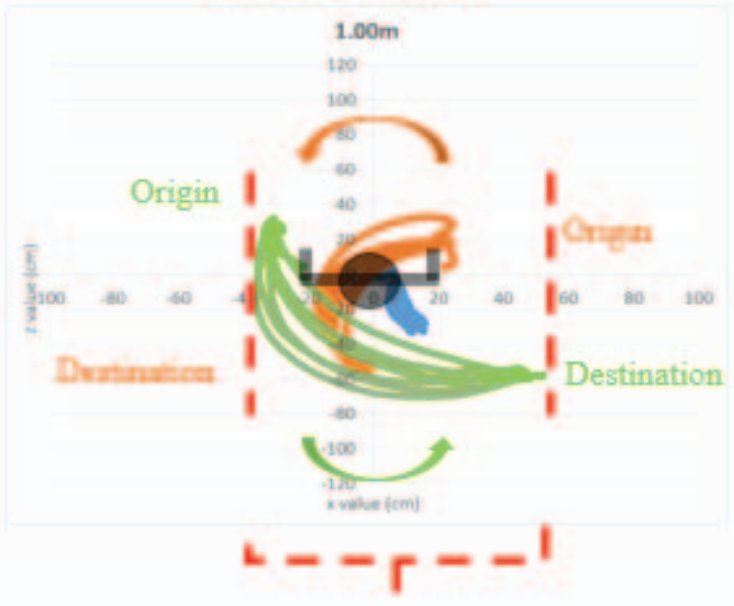

Width requirements

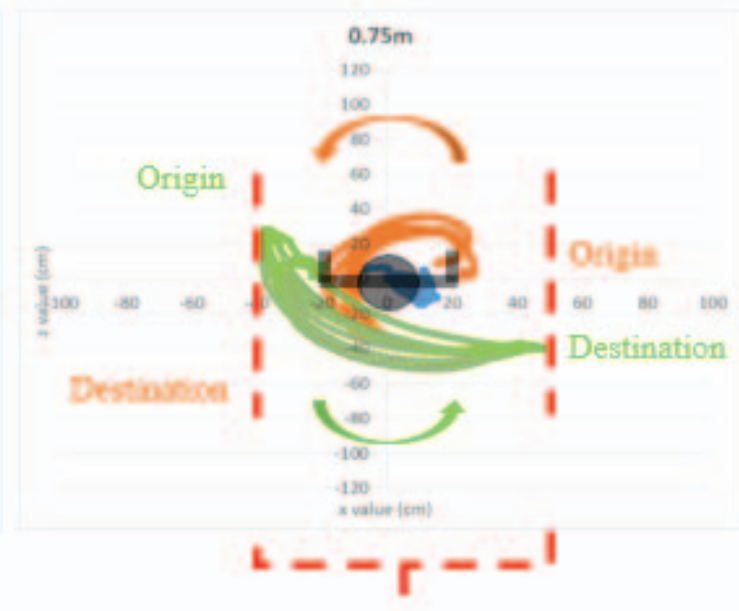

Width requirements

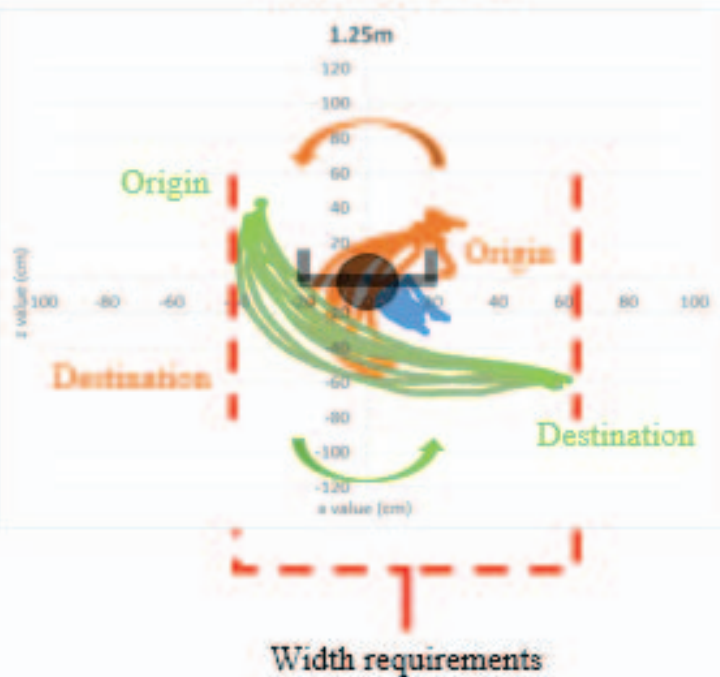

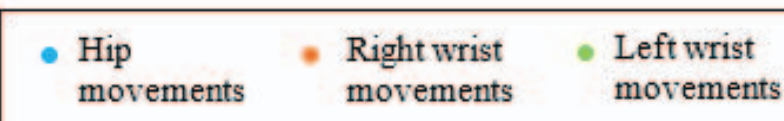

Movement direction of right wrist

\section{Movement direction of left wrist}

Fig. 9: Width requirements of wrists and hip motion of manual transfer for different distances for Subject 23. 
Table 1: Maximum value, mean and standard deviation of width requirements for all subjects $(n=26)$ at different transfer distances.

\begin{tabular}{cccc}
\hline Transfer distance $(\mathbf{m})$ & \multicolumn{3}{c}{ Width requirements $(\mathbf{c m})$} \\
\cline { 2 - 4 } & Maximum & Mean & Standard Deviation \\
0.50 & 92.02 & 74.84 & 10.26 \\
0.75 & 93.73 & 74.18 & 8.81 \\
1.00 & 109.41 & 78.95 & 12.07 \\
1.25 & 108.02 & 83.42 & 14.01 \\
\hline
\end{tabular}

Table 2: Post Hoc analysis to compare significance differences in width requirements between transfer distances.

\begin{tabular}{cccccc}
\hline \multicolumn{2}{c}{$\begin{array}{c}\text { Comparison of transfer } \\
\text { distances }\end{array}$} & $\begin{array}{c}\text { Mean } \\
\text { Difference }\end{array}$ & $\begin{array}{c}\text { Standard } \\
\text { Error }\end{array}$ & t & P bonferroni \\
\hline $0.5 \mathrm{~m}$ & $0.75 \mathrm{~m}$ & 0.654 & 1.818 & 0.360 & 1.000 \\
& $1.0 \mathrm{~m}$ & -4.111 & 2.060 & -1.996 & 0.342 \\
$0.75 \mathrm{~m}$ & $1.25 \mathrm{~m}$ & -8.586 & 2.660 & -3.228 & $\mathbf{0 . 0 2 1 *}$ \\
& $1.0 \mathrm{~m}$ & -4.765 & 1.686 & -2.827 & 0.055 \\
\multirow{3}{*}{$1.0 \mathrm{~m}$} & $1.25 \mathrm{~m}$ & -9.240 & 2.502 & -3.693 & $\mathbf{0 . 0 0 7}$ \\
& $1.25 \mathrm{~m}$ & -4.474 & 2.089 & -2.142 & 0.253 \\
\hline
\end{tabular}

Note: * signifies statistical significant difference

\section{DISCUSSION}

Comparing images visualized from MVN Studio software, it was found that the $0.50 \mathrm{~m}$ transfer distance encourages twisting the most, compared to longer transfer distances. The limited space and clearance encouraged subjects to stand relatively static at one place and twist the body while transferring the box. When the transfer distance increased, subjects were able to make some movements while transferring the box causing less possession of twisting, but it was observed that bending posture was more prominent. In general, hip movement is more dynamic at larger space but the hip position is still within the same relative area (not spread around). This indicates that the subjects tended to move more but were still standing on the same spot. In order to complete the transfer task, subjects tended to bend more during lifting and placing the box in order to reach the stations.

The positional data of hip and wrists for different transfer distances during manual transfer were mapped to give an overview of the space requirements. Overall, the result showed that in the shortest setup $(0.5 \mathrm{~m})$, hip positional data are mostly localized in one area, while the wrist motions are in a semi-circular shape. The relatively static hip data suggested that the subjects were adopting twisting motion during the transfer process. As the transfer distances increased, the curve pattern for hip and wrists positional data stretched out and resulted in a more stretched curve pattern. This suggests more dynamic motions occur during the transfer process, comprising of both body movements and bending, compared to primarily twisting movements in the shortest setup at $0.5 \mathrm{~m}$ transfer distance.

Body postures during material handling can be influenced by the distance between the lifting origin and the destination stations. Findings from this study show that the magnitude of lower back bending increases as the transfer distance increases. This result is in agreement with a study by Metha et al. [5] which found that the increase of separation 
distance might increase forward flexion of the spine. This posture pose may happen due to the tendency of the workers to reach rather than stepping toward to the destination station. The authors added that longer transfer distance can also increase physiological cost and transfer time of the handlers. Meanwhile, if the transfer distances between the origin and destination stations were too close to each other, workers were more likely to adopt a twisting motion due to limited space and clearances. In another study, Kuorinka and Ilkka [10] also found that limited workspaces and clearances may result in workers adopting incorrect material handling methods. Overall, results in this study are aligned to findings from other researchers that suggest increase in lower back bending magnitude, and decrease in lower back twisting magnitude, as the transfer distances increased. However, the detailed analyses on these trends were not the primary focus of this manuscript. The detailed measurement, analysis, and description on the trends of lower back bending and twisting during different transfer distances had been documented in the authors' other manuscript.

The principle of correct manual carrying is by holding the object as close to the body as possible while keeping the back straight [15]. A study conducted by Dolan et al. [17] found that the activity of lifting a weight that is farther in front of the body as one of the parameters contributing to a substantial increment in extensor moment of the spine. Extensor moment is the tension in the thin muscle groups running at every side of the vertebral column of the body, and can be an indirect measure of the compressive force acting on the spine. In addition, multiple studies have established that lower back bending and twisting cause biomechanical load on lower back, hence increasing the risk for lower back pain $[18,19]$. For example, a case study in Malaysian automotive manufacturing company reported that lower back pain is the highest prevalence of MSD among workers [20]. The authors claimed that the workers were found to perform the MMH tasks with improper work postures and incorrect techniques. Poor handling, in combination with poor postures may affect the function and efficiency of muscle forces. Muscle forces are increased when there are asymmetrical postures during bending and twisting of lower back [21]. The asymmetry in muscle activity occurs due to generation of mechanical stiffness by different sets of muscles for spine stabilization process, and this may eventually lead to unequal stress concentrations on the different component structures of the spine. Cholewicki and McGill [22] in a lumbar spine modelling study showed that reduction in passive joint and muscle stiffness in various postures may affect mechanical stability of the spine, consequently increasing the risk of development of chronic back pain.

Marras and Granata [18] reported that bending and twisting can cause compres sional and shear force loadings on spine discs. Compressive force and shear force exerted on the intervertebral discs increase as the velocity and acceleration of the trunk increase, which may happen due to sideways bending and twisting activities. During material handling tasks, the gravitational force, initial force of body segments and hand load notable to L5 S1 of spine may cause the upper body to torque-tilt at the lumbosacral (L5-S1) joint [23]. This torque depends on the motion of the spine and on the acceleration of the body segments, as well as the load. As such, transfer distances at two extremes (too short or too far away) would increase risks to musculoskeletal strain. An appropriate transfer distance that can balance between bending and twisting would reduce biomechanical load, musculoskeletal strain, and ultimately risks to musculoskeletal disorders or injuries. Even though many industries have been providing supporting devices and techniques on proper material handling to their workers, they may not be effective enough in preventing back pain among workers [24]. As such, practitioners may also include consideration of 
appropriate transfer distance as it can influence the magnitude of bending and twisting activities in manual handling tasks.

The positional data showed that the different transfer distances may also affect wid th requirements, consequently the overall space requirement. The data across subjects showed similar width requirements between $0.5 \mathrm{~m}$ and $0.75 \mathrm{~m}$ transfer distances $(\mathrm{mean}=$ $74.84 \mathrm{~cm}, \mathrm{SD}=10.26 \mathrm{~cm}$ for $0.5 \mathrm{~m}$, and mean $=74.18 \mathrm{~cm}, \mathrm{SD}=8.81 \mathrm{~cm}$ for $0.75 \mathrm{~m}$ ). These two transfer distances encourage more twisting, due to limited clearance. As such, this might result in the subjects to naturally pulling the box close to the body during the transferring process of both $0.5 \mathrm{~m}$ and $0.75 \mathrm{~m}$ transfer distances, hence explaining why the width requirements were similar. As the transfer distance increases, the data trend suggests that the width requirement increases as well (mean $=78.95 \mathrm{~cm}, \mathrm{SD}=12.07 \mathrm{~cm}$ for $1.0 \mathrm{~m}$, and mean $=83.42 \mathrm{~cm}, \mathrm{SD}=14.01 \mathrm{~cm}$ for $1.25 \mathrm{~m}$ ). At further transfer distance, the body posture seems to shift from primarily twisting to twisting plus forward bending. As subjects were bending forward, the hands naturally extended out in an effort to span the reaching distances. This is likely to explain the extension of the width requirements in further transfer distances.

The repeated measures ANOVA found that there were significant differences in width requirements between transfer distances of $0.5 \mathrm{~m}$ vs $1.25 \mathrm{~m}$, and $0.75 \mathrm{~m}$ vs $1.25 \mathrm{~m}$ at alpha $=0.05$. Since width requirements for transfer distances of $0.5 \mathrm{~m}$ and $0.75 \mathrm{~m}$ were similar, it can be argued that $0.75 \mathrm{~m}$ transfer distance does not take significantly larger areas than $0.5 \mathrm{~m}$, but at the same time provide larger clearance between the transfers. On the other hand, the $1.25 \mathrm{~m}$ transfer distance showed significant difference in width requirement as compared to $0.5 \mathrm{~m}, 0.75 \mathrm{~m}$, and $1.0 \mathrm{~m}$ transfer distances, which indicates that it will take larger space area. When translated to area requirements, $1.25 \mathrm{~m}$ transfer distance on average consumed $64 \%$ larger area than $0.5 \mathrm{~m}, 46 \%$ larger area than $0.75 \mathrm{~m}$, and 24\% larger area than $1 \mathrm{~m}$ transfer distances. Larger space area requirement resulted in additional real estate, which indirectly translated to higher capital and costs. As such, it can be interpreted from data obtained in this study that the optimum transfer distance may be between 0.75 and $1.0 \mathrm{~m}$. In this range, there is a middle ground in which the lifters do not have to adopt extreme twisting and forward bending. In addition, the differences in width requirements are marginal. This can provide the trade-off between postural adoption and space requirements when performing the manual transfer task. It should be noted that study by Lavender and Johnson [6] suggest that twisting and lateral movement would be minimized when the transfer distances were between 1 and 1.25 meters. The differences may come due to experimental setups, measures, and subject populations.

\section{CONCLUSION}

This study provides a visual mapping of hands and hip movements of manual transfer at four different distances, $0.50 \mathrm{~m}, 0.75 \mathrm{~m}, 1.00 \mathrm{~m}$ and $1.25 \mathrm{~m}$. Based on observation of twisting and bending of subjects in motion capture software, and through visualization of hip and hand wrists motion top view mapping, it can be seen that the pattern of the hip motion changes from mostly static to more dynamic movements as the distance increases. In addition, patterns for wrists motions change from a semi-circular shape to a more stretched semi-circular shape as the transfer distance increases. Shorter transfer distance encourages low back twisting while minimizing bending, whereas the increase of transfer distance reduces the magnitude of low back twisting while individuals adopt more bending postures. As such, the motions of the hip and wrists during the manual handling process were affected by the transfer distance. In addition, the study also found that transfer 
distances affect space requirements. As transfer distance increases, the data trend suggests that the width requirement also increases, due to shifting from primarily twisting to twisting plus forward bending. Forward bending and arm extension were adopted by subjects to increase their reaching range in further transfer distances, which consequently affect the space requirements. The study suggests that the optimum transfer distance may be between 0.75 and $1.0 \mathrm{~m}$, in which there is a balance between extreme twisting and bending. In summary, it can be concluded that the difference in transfer distance does affect the space requirement as well as the postures possessed during manual handling activity. This provides guidance for engineers in designing workplace lay outs as well as space requirements related to manual transfer tasks, especially in the early engineering design stage.

\section{ACKNOWLEDGEMENTS}

The authors are grateful to the Malaysian government, Universiti Teknikal Malaysia Melaka (UTeM) for supporting this study. The study is partially funded by research grant INDUSTRI (IRMG) / ERGOWORKS / 2019 / FKP-COSSID / I00037. The authors acknowledge Lee Poh Yan and Nur Izzati Azri for their contributions in this study.

\section{REFERENCES}

[1] Duly J, Neumann WP. (2009) Ergonomic contributions to company strategies. Applied Ergonomics, 40(4):745-752.

[2] Coenen P, Gouttebarge V, van der Burght AS, van Dieën JH, Frings-Dresen MH, van der Beek AJ, Burdorf A. (2014) The effect of lifting during work on low back pain: a health impact assessment based on a meta-analysis. Occupational and Environmental Medicine, 71(12): 871-877.

[3] Deros BM, Daruis DDI, Rosly AL, Aziz IA, Hishamuddin NS, Hamid NHA, Roslin SM. (2017) Ergonomic risk assessment of manual material handling at an automotive manufacturing company. Press Academia Procedia, 5:317-324.

[4] Mital A. (2017) Guide to manual materials handling, London.

[5] Mehta JP, Kim TH, Weiler MR, Lavender SA. (2014) Effects of transfer distance on spine kinematics for de-palletizing tasks. J. of Occupational and Environmental Hygiene, 11(1):18.

[6] Lavender SA, Johnson M. (2009) Is there a transfer distance that minimizes twisting and bending motions of the spine?. In Proceedings of the Human Factors and Ergonomics Society Annual Meeting, 53(14):882-882.

[7] Lavender SA, Lorenz EP, Andersson GB. (2007) Can a new behaviorally oriented training process to improve lifting technique prevent occupationally related back injuries due to lifting?. Spine, 32(4):487-494.

[8] Daltroy LH, Iversen MD, Larson MG, Lew R, Wright E, Ryan J, Liang MH. (1997) A controlled trial of an educational program to prevent low back injuries. New England J. of Medicine, 337(5):322-328.

[9] Karwowski W. (2005) Ergonomics and human factors: the paradigms for science, engineering, design, technology and management of human-compatible systems. Ergonomics, 48(5):436-463.

[10] Kuorinka I, Lortie M, Gautreau M. (1994) Manual handling in warehouses: the illusion of correct working postures. Ergonomics, 37(4):655-661.

[11] Shamsuddin KA, Ani MNC, Ab-Kadir AR, Osman MH. (2014) Analysis on the workrelated musculoskeletal disorders (WMSD's) based on ergonomic study in case of industry study. International J. of Engineering Research, 3(4):190-195. 
[12] Yahya NM, Zahid MNO. (2018) Work-related musculoskeletal disorders (WMDs) risk assessment at core assembly production of electronic components manufacturing company. In IOP Conference Series: Materials Science and Engineering, 319(1):012036.

[13] Kazmierczak K, Neumann WP, Winkel J. (2007) A case study of serial-flow car disassembly: ergonomics, productivity and potential system performance. Human Factors and Ergonomics in Manufacturing \& Service Industries, 17(4):331-351.

[14] Cheung Z, Feletto M, Galante J, Waters T, Centers for Disease Control and Prevention. (2007) Ergonomic guidelines for manual material handling. In NIOSH Publication, 2007131.

[15] Department of Occupational Safety and Health. (2018) Guidelines for manual material handling at workplace 2018, Malaysia.

[16] Mohamad D, Deros BM, Ismail AR, Daruis DDI. (2010) Development of a malaysian anthropometric database. In Conference on Manufacturing Technology and Management.

[17] Dolan P, Earley M, Adams MA. (1994) Bending and compressive stresses acting on the lumbar spine during lifting activities. J. of Biomechanics, 27(10):1237-1248.

[18] Marras WS, Granata KP. (1997) The development of an EMG-assisted model to assess spine loading during whole-body free-dynamic lifting. J. of Electromyography and Kinesiology, 7(4):259-268.

[19] Plamondon A, Denis D, Delisle A, Larivière C, Salazar E, IRSST MMH research group. (2010) Biomechanical differences between expert and novice workers in a manual material handling task. Ergonomics, 53(10):1239-1253.

[20] Deros BM, Daruis DD, Ismail AR, Sawal NA, Ghani JA. (2010) Work-related musculoskeletal disorders among workers' performing manual material handling work in an automotive manufacturing company. American J. of Applied Sciences, 7(8):1087.

[21] Pope MH, Andersson GBJ, Broman H, Svensson M, Zetterberg C. (1986) Electromyographic studies of the lumbar trunk musculature during the development of axial torques. J. of Orthopaedic Research, 4(3):288-297.

[22] Cholewicki J, McGill SM. (1996) Mechanical stability of the in vivo lumbar spine: implications for injury and chronic low back pain. Clinical Biomechanics, 11(1):1-15.

[23] Jager M, Luttmann A. (1992) The load on the lumbar spine during asymmetrical bi-manual materials handling. Ergonomics, 35(7-8):783-805.

[24] Verbeek JH, Martimo KP, Karppinen J, Kuijer PPF, Viikari-Juntura E, Takala EP. (2011) Manual material handling advice and assistive devices for preventing and treating back pain in workers. Cochrane Database of Systematic Reviews, (6). 